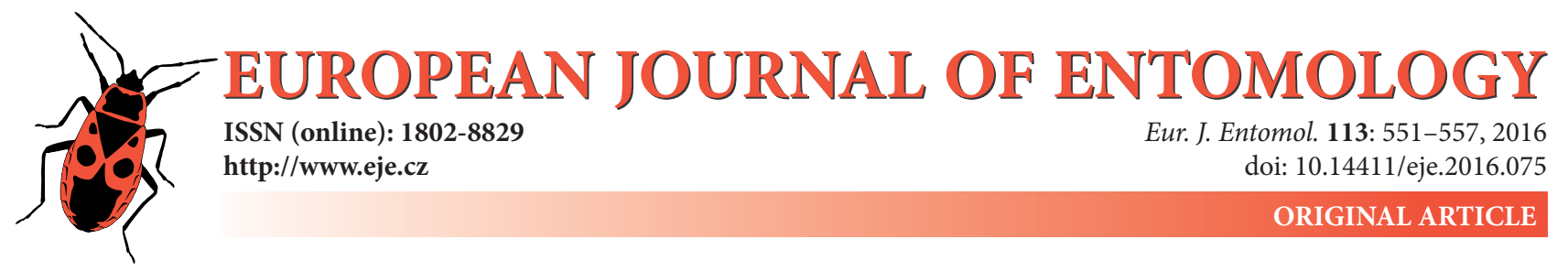

\title{
Tri-trophic interaction involving host plants, black legume aphid, Aphis craccivora (Hemiptera: Aphididae) and the predator, Cheilomenes sexmaculata (Coleoptera: Coccinellidae)
}

\author{
Snehasish ROUTRAY and KaRnam V. HARI PRASAD* \\ Department of Entomology, S.V. Agricultural College, Tirupati 517 501, Angrau, Andhra Pradesh, India; \\ e-mails: snehasishroutray@gmail.com,kvhp@hotmail.com
}

Key words. Hemiptera, Aphididae, Aphis craccivora, Coleoptera, Coccinellidae, Cheilomenes sexmaculata, tri-trophic interaction, host plants, aphids, coccinellid

\begin{abstract}
Interactions involving host plants (cowpea, groundnut, cotton, sunflower, greengram, blackgram) an insect herbivore, black legume aphid Aphis craccivora Koch (Hemiptera: Aphididae) and a predator, the zigzag beetle Cheilomenes sexmaculata (Fabricius) (Coleoptera: Coccinellidae) were investigated during 2014-2015. The preference of the aphid A. craccivora for host plants measured in terms of growth and multiplication was cowpea $>$ groundnut $>$ greengram $>$ blackgram $>$ sunflower $>$ cotton (most preferred to least preferred). Cowpea was the most preferred host plant for growth and multiplication of $A$. craccivora. Aphid's oviposition period was longest, fecundity greatest; adult longevity longest $(188.40 \pm 28.87 \mathrm{~h} ; 52.00 \pm 10.92 ; 231.60 \pm 40.41$ h), and nymphal mortality was lowest $(0 \%)$ when reared on cowpea followed by groundnut, greengram and blackgram. Aphids had highest nymphal mortality (100\%), with very few or no live adults produced, when reared on sunflower and cotton, the least preferred host of $A$. craccivora in this study. At the third trophic level, both the larvae and the adults of the coccinellid, Cheilomenes sexmaculata, consumed more of the aphids reared on groundnut than of those reared on blackgram, greengram, cowpea, sunflower and cotton. The biochemical constituents (phenols) present in cotton and sunflower, which contributed to the aphid's nymphal mortality, also affected the feeding behaviour of the coccinellid.
\end{abstract}

\section{INTRODUCTION}

Plants interact in complex ways with the herbivores and pathogens that feed on them and also with the natural enemies of the herbivores and pathogens (Price et al., 1980). The role of plant chemistry (primary and secondary metabolites) in tri-trophic interactions is central to several aspects of trophic phenomena including, top-down versus bottom-up control of herbivores, enemy-free space and host choice and theories of plant defence. The effects of plant defence on natural enemies i.e. parasitoids and predators, depends on the specific attributes of the plant trait and the details of the physical, biochemical, and behavioural interactions between the natural enemies, their hosts (prey) and the host plant (Kennedy, 2003). Plant defence traits viz., primary and secondary metabolites and their chemistry are important in assessing the degree of compatibility between biological control and plant resistance approaches to pest control (Ode, 2006).

Aphids are major insect pests in both tropical and temperate regions (Francis et al., 2000) of the world causing direct and indirect (as vectors) damage to cultivated crops.
The aphid, A. craccivora, is highly polyphagous as it is recorded feeding on plants belonging to 80 plant families. Crops attacked by this aphid include brassicas, cucurbits, beetroot, groundnut, cotton, cowpeas, chickpeas, cardamom, etc. (CABI, 2013). The zigzag beetle, C. sexmaculata (Fabricius), is an important aphidophagous predator in Asia (Zhao et al., 2015). This predatory beetle feeds on a wide range of soft bodied insects such as aphids, plant hoppers, thrips, jassids, scale insects, mealy bugs and white flies, infesting a large number of crops (Rahman et al., 1993; Solangi et al., 2007). The biology and feeding potential of some coccinellids viz, Harmonia axyridis, Hippodamia convergens, Coccinella septempunctata, Adalia bipunctata L. and Propylea japonica, is affected by the host plants of their prey (first trophic level) (Durcher et al., 1999; Giles et al., 2002; Down et al., 2003; Du et al., 2004; Jalali \& Michaud 2012; Barkhordar et al., 2013).

This paper present the results of a study of tritrophic interactions involving six host plants (cowpea, groundnut, cotton, sunflower, greengram and blackgram), an insect

\footnotetext{
* Corresponding author; e-mail: kvhp@hotmail.com
} 
herbivore, A. craccivora, and an insect predator, C. sexmaculata.

\section{MATERIALS AND METHODS}

Host plants viz, Cowpea, Vigna unguiculata (L.) Walp. (var. GC-3), Groundnut, Arachis hypogaea L. (Var. K-6), Cotton, Gossypium hirsutum L. (Var. Narasimha), Sunflower, Helianthus annuus L. (Var. DRSH-1), Greengram, Vigna radiate (L.) R. Wilczek (Var. LGG-410) and Blackgram, Vigna mungo (L.) Hepper (Var. LBG-791), were grown in plastic pots $(23 \mathrm{~cm}$ in diameter and $20 \mathrm{~cm}$ high) during Kharif (south-west monsoon season) 2014-2015 from August onwards in the Department of Entomology, S.V. Agricultural College, ANGRAU, Tirupati, Andhra Pradesh, India. Planting dates of all the host plants were adjusted so that they reached the same physiological state of maturity (peak vegetative stage (Cowpea 35 to 40 DAS (Days After Sowing), Groundnut 35 to 40 DAS, Cotton 25 to 30 DAS, Sunflower 35 to 40 DAS, Greengram 35 to 40 DAS and Blackgram 35 to 40 DAS)), at the time of the experiment. The substrate used for growing plants was red soil : compost in a $3: 1$ ratio in plastic pots $23 \mathrm{~cm} \times 20 \mathrm{~cm}$. The seeds of the test plants were treated with fungicides (Mancozeb @ $2 \mathrm{gKg}^{-1}$ ) to prevent fungal diseases.

\section{Studies on the biology of $A$. craccivora}

Biology of the aphid A. craccivora was studied in the laboratory at $28 \pm 2^{\circ} \mathrm{C}$ and $75-80$ per cent $\mathrm{RH}$. The second or third freshly opened leaves of the host plants at the peak vegetative stage were used for studying the biology of the aphid. The leaves were excised and placed singly in $9 \mathrm{~cm}$ diameter glass Petri dishes. To keep the leaves fresh, the Petri dishes were lined with moist blotting paper. One first instar nymph of the aphid was placed on each of the excised leaves. Development of the aphids in terms of number of moults, duration of each instar, nymphal mortality, adult longevity and adult fecundity was recorded every $12 \mathrm{~h}$ There was a total of 20 replications per host plant. Body length, body width, head capsule width, antennal length, cornicle length and caudal length of all the nymphal instars and adult aphids, reared on the six host plants were measured using an ocular micrometer. There was a total of ten replicates per host plant and the data were expressed in millimeters.

\section{Plant biophysical characters}

\section{Trichome density}

Trichome density was measured on the abaxial surfaces of the leaves of the six host plants. Number of trichomes on a $0.25 \mathrm{~cm}^{2}$ area of leaf was counted and expressed as number of trichomes per $0.25 \mathrm{~cm}^{2}$ leaf area.

\section{Plant biochemical constituents}

Plant biochemical constituents, such as protein content (Lowry et al., 1951), total carbohydrates (Hedge \& Hofreiter, 1962), total free amino acids (Moore \& Stein, 1948), total phenol content
(Malick \& Singh, 1980) and total reducing sugars (Somogyi, 1952) were estimated from fresh leaves of the six host plants as per the above protocols. There were five replicates for each host plant. Both the biophysical and biochemical constituents of host plants were correlated with the aphid's performance on these plants.

\section{Number of aphids consumed by $C$. sexmaculata}

The stock culture of the coccinellid, C. sexmaculata, was kept in a laboratory. Initially pupal stages were collected en masse from nearby agricultural fields. These pupae were kept in plastic boxes, $9 \mathrm{~cm} \times 14 \mathrm{~cm}$, till adult emergence. The adults were provided with aphids reared on cowpea. The eggs laid on the walls of the plastic boxes were collected and the larvae and adult beetles that developed from them were used to determine the number of aphids they consume.

Newly hatched first instar larvae were placed in small plastic containers $(7 \mathrm{~cm} \times 4 \mathrm{~cm})$ and provided with third and fourth instar nymphs of $A$. craccivora. The larvae were provided with known numbers of aphids and after $24 \mathrm{~h}$, the numbers of live aphids were counted and the total number of aphids consumed by the larvae recorded. The values were expressed as total no. of aphids consumed by each larva. The aphids were provided with a small piece of leaf of the respective host plant. The same procedure was followed for determining the number of aphids consumed by the adult beetles.

\section{Statistical analysis}

All the data were subjected to ANOVA and DMRT analysis using the SPSS 13.0 software package (SPSS Inc., 2004).

\section{RESULTS}

Shortest nymphal development of the aphid, A. craccivora was recorded when they were reared on cowpea $(104.40 \pm 8.09 \mathrm{~h})$ and groundnut $(103.20 \pm 14.08 \mathrm{~h})$ followed by those reared on greengram and blackgram $(124.8 \pm 10.11 \mathrm{~h}$ and $123.6 \pm 18.80 \mathrm{~h}$, respectively) (Table 1).

On cotton and sunflower, none of the aphids completed its nymphal development and died before reproducing. The nymphal duration of each instar was recorded for those survived but did not moult into the next instar..

Of all the host plants tested, aphids had the shortest developmental times $(104.40 \pm 8.09 \mathrm{~h})$, longest oviposition period $(188.40 \pm 28.87 \mathrm{~h})$ and highest fecundity $(52.00 \pm 10.92)$, when reared on cowpea, followed by those reared on groundnut (fec. 21.12 \pm 2.64 ), greengram (fec. $12.62 \pm 8.38$ ) and blackgram (fec. 9.87 \pm 8.67 ) (Table 1 and 2).

Table 1. Duration (in h) and percentage mortality in the nymphal instars of $A$. craccivora reared on the six different host plants.

\begin{tabular}{lcccccc}
\hline Host plants & $\begin{array}{c}\text { First instar } \\
\pm \text { S.D. }\end{array}$ & $\begin{array}{c}\text { Second instar } \\
\pm \text { S.D. }\end{array}$ & $\begin{array}{c}\text { Third instar } \\
\pm \text { S.D. }\end{array}$ & $\begin{array}{c}\text { Fourth instar } \\
\pm \text { S.D. }\end{array}$ & $\begin{array}{c}\text { Total nymphal } \\
\text { duration } \pm \text { S.D. }\end{array}$ & $\begin{array}{c}\text { Nymphal mortality } \\
\pm \text { S.D. (\%) }\end{array}$ \\
\hline Cowpea & $30.00^{\mathrm{b}} \pm 8.48$ & $24.00^{\mathrm{ab}} \pm 13.85$ & $26.40^{\mathrm{a}} \pm 5.05$ & $24.00^{\mathrm{ab}} \pm 8.00$ & $104.40^{\mathrm{b}} \pm 8.09$ & $0.00^{\mathrm{a}} \pm 0.00$ \\
Groundnut & $27.60^{\mathrm{b}} \pm 5.79$ & $34.80^{\mathrm{cd}} \pm 8.85$ & $21.60^{\mathrm{a}} \pm 2.99$ & $19.20^{\mathrm{a}} \pm 8.39$ & $103.20^{\mathrm{ab}} \pm 14.08$ & $20.00^{\mathrm{a}} \pm 42.16$ \\
Greengram & $19.20^{\mathrm{a}} \pm 6.19$ & $39.60^{\mathrm{d}} \pm 5.79$ & $38.40^{\mathrm{b}} \pm 9.46$ & $27.60^{\mathrm{b}} \pm 5.79$ & $124.8^{\mathrm{a}} \pm 10.11$ & $20.00^{\mathrm{a}} \pm 42.16$ \\
Blackgram & $19.20^{\mathrm{a}} \pm 6.19$ & $39.60^{\mathrm{d}} \pm 5.79$ & $34.80^{\mathrm{b}} \pm 15.44$ & $30.00^{\mathrm{b}} \pm 8.48$ & $123.6^{\mathrm{c}} \pm 18.80$ & $20.00^{\mathrm{a}} \pm 42.16$ \\
Sunflower & $20.40^{\mathrm{a}} \pm 5.79$ & $30.00^{\mathrm{abc}} \pm 6.32$ & $36.00^{\mathrm{b}} \pm 0.00$ & $24.00^{\mathrm{ab}} \pm 0.00$ & $--^{1}$ & $100^{\mathrm{b}} \pm 0.00$ \\
Cotton & $27.60^{\mathrm{b}} \pm 8.09$ & $16.80^{\mathrm{a}} \pm 6.19$ & $24.00^{\mathrm{a}} \pm 0.00$ & $24.00^{\mathrm{ab}} \pm 0.00$ & $--^{1}$ & $100^{\mathrm{b}} \pm 0.00$ \\
\hline
\end{tabular}

${ }^{1}$ Total nymphal durations were not calculated (as explained in the text). Values followed by the same letter are not significantly different at 0.05 level as per DMRT. 
Table 2. Post nymphal developmental periods (in h), adult longevity and fecundity of $A$. craccivora reared on the different host plants.

\begin{tabular}{|c|c|c|c|c|c|c|}
\hline Host plants & $\begin{array}{l}\text { Pre-oviposition } \\
\text { period } \pm \text { S.D. }\end{array}$ & $\begin{array}{c}\text { Oviposition } \\
\text { period } \pm \text { S.D. }\end{array}$ & $\begin{array}{l}\text { Post-oviposition } \\
\text { period } \pm \text { S.D. }\end{array}$ & $\begin{array}{c}\text { Adult } \\
\text { longevity } \pm \text { S.D. }\end{array}$ & $\begin{array}{c}\text { Total life } \\
\text { span } \pm \text { S.D. }\end{array}$ & $\begin{array}{c}\text { Fecundity } \\
\text { (in no.) } \pm \text { S.D. }\end{array}$ \\
\hline Cowpea & $14.4^{a} \pm 5.05$ & $188.40^{\mathrm{c}} \pm 28.87$ & $28.80^{\mathrm{b}} \pm 12.89$ & $231.60^{b} \pm 40.41$ & $336.00^{b} \pm 37.94$ & $52.00^{b} \pm 10.92$ \\
\hline Groundnut & $15.00^{\mathrm{a}} \pm 5.55$ & $85.50^{a} \pm 11.89$ & $25.50^{\mathrm{ab}} \pm 7.69$ & $100.80^{a} \pm 54.61$ & $204.00^{a} \pm 57.96$ & $21.12^{\mathrm{a}} \pm 2.64$ \\
\hline Greengram & $15.00^{\mathrm{a}} \pm 5.55$ & $96.00^{b} \pm 62.51$ & $13.50^{\mathrm{ab}} \pm 10.01$ & $99.60^{a} \pm 77.36$ & $224.40^{\mathrm{a}} \pm 81.98$ & $12.62^{\mathrm{a}} \pm 8.38$ \\
\hline Blackgram & $22.50^{\mathrm{b}} \pm 10.01$ & $75.00^{\mathrm{ab}} \pm 63.74$ & $10.50^{a} \pm 10.01$ & $86.40^{\mathrm{a}} \pm 73.27$ & $210.00^{\mathrm{a}} \pm 66.03$ & $9.87^{a} \pm 8.67$ \\
\hline Sunflower & - & - & - & - & - & - \\
\hline Cotton & - & - & - & - & - & - \\
\hline
\end{tabular}

Values followed by same letter are not significantly different at 0.05 level as per DMRT.

In terms of size of the fourth instar, aphids reared on cowpea were significantly larger $(1.56 \pm 0.01 \mathrm{~mm} \times 0.80 \pm 0.00$ $\mathrm{mm}$ ) than those reared on the other plants. Smallest body size of the fourth instar was recorded for the aphids reared on groundnut $(1.25 \pm 0.03 \mathrm{~mm} \times 0.54 \pm 0.01 \mathrm{~mm})$. The average head capsule width of the fourth instar aphids reared on cowpea $(0.36 \pm 0.00 \mathrm{~mm})$ was greater than that of aphids reared on blackgram $(0.33 \pm 0.00)$ (not significantly different), groundnut and greengram $(0.32 \pm 0.00)$ (not significantly different) (Table 3).

The same trend in size was also recorded for adult aphids. Maximum adult body size was greater when they were reared on cowpea $(2.33 \pm 0.14 \mathrm{~mm} \times 1.18 \pm 0.02$ $\mathrm{mm}$ ) than on greengram; blackgram and groundnut (significantly different). Similarly, the maximum head capsule width of the adults reared on cowpea $(0.44 \pm 0.02 \mathrm{~mm})$ was greater than that of aphids reared on greengram and blackgram (significantly different). The smallest head capsule widths of adults was recorded for aphids reared on groundnut $(0.32 \pm 0.00 \mathrm{~mm})$ (significantly different from those of aphids reared on the other host plants) (Table 4).

Least trichome density was recorded for cowpea $(0.00 \pm 0.00)$ followed by the other host plants. Highest trichome density was recorded for cotton $(265.9 \pm 78.97$ hairs/0.25 $\mathrm{cm}^{2}$ leaf area) followed by sunflower $(152.1 \pm 42.89)$ (both of which differ significantly from those of the other host plants). There is no statistically significant difference between the leaf trichome density of blackgram $(86.7 \pm 23.65)$ and greengram $(78.8 \pm 19.43)$ (Table 5).

Of all the host plants the highest protein content was recorded in the leaves of cowpea $(335.21 \pm 29.58 \mathrm{mg} / \mathrm{g})$ followed by cotton $(306.06 \pm 71.92 \mathrm{mg} / \mathrm{g})$ and blackgram (275.01 $\pm 76.73 \mathrm{mg} / \mathrm{g})$ (not significantly different). The lowest protein content was recorded in leaves of sunflower $(139.53 \pm 26.13 \mathrm{mg} / \mathrm{g})$, which is significantly lower than that recorded in the leaves of all the other host plants. The leaf protein content of greengram and groundnut are intermediate between those of cowpea and sunflower.

Total soluble sugar content was highest in the leaves of sunflower $(16.14 \pm 1.76 \mathrm{mg} / \mathrm{g})$ followed by cowpea $(13.04 \pm 1.34 \mathrm{mg} / \mathrm{g})$ (significantly different). The least TSS content was recorded in cotton $(5.53 \pm 0.92 \mathrm{mg} / \mathrm{g})$ followed by groundnut $(7.49 \pm 2.06 \mathrm{mg} / \mathrm{g}$ ) (not significantly different) and those in the leaves of greengram (11.22 \pm 0.82 $\mathrm{mg} / \mathrm{g})$ and blackgram $(10.06 \pm 1.74)$ are intermediate between those of sunflower and cotton.

Total phenol content was highest in the leaves of cotton $(260.46 \pm 31.43 \mathrm{mg} / \mathrm{g})$ followed by that in the rest of the host plants (significantly different). Least total phenol content was recorded in leaves of cowpea (49.29 \pm 17.04 $\mathrm{mg} / \mathrm{g})$.

Cowpea leaves had the highest quantity of total free amino acids $(5.68 \pm 2.26 \mathrm{mg} / \mathrm{g})$ followed by those of greengram $(4.04 \pm 1.06 \mathrm{mg} / \mathrm{g})$ and groundnut $(3.49 \pm 0.82)$ (not significantly different). The least quantity was recorded in the leaves of sunflower $(0.40 \pm 0.41 \mathrm{mg} / \mathrm{g})$, followed by cotton $(1.24 \pm 0.54 \mathrm{mg} / \mathrm{g})$ and blackgram $(2.32 \pm 0.47 \mathrm{mg} / \mathrm{g})$.

Highest total reducing sugars were recorded in leaves of sunflower $(3.15 \pm 0.23 \mathrm{mg} / \mathrm{g})$ followed by the leaves of the other host plants (Table 5). The lowest total reducing sugars were recorded in the leaves of cowpea $(1.82 \pm 0.38 \mathrm{mg} / \mathrm{g})$, groundnut $(1.96 \pm 0.22 \mathrm{mg} / \mathrm{g})$ and greengram $(2.06 \pm 0.08$ $\mathrm{mg} / \mathrm{g}$ ) (not significantly different) (Table 5).

Correlations between the aphid's performance (in terms of biological parameters) and plant physical and biochemical constituents of the various host plants, revealed that the density of trichomes on the leaves of the different host plants were significantly negatively correlated with adult longevity $(\mathrm{r}=-0.752$, fecundity $(\mathrm{r}=-0.799)$, total life cycle $(\mathrm{r}=-0.762)$ and a significantly positively correlated with percentage nymphal mortality $(\mathrm{r}=0.682)$ (Table 6).

In terms of the biochemical constituents, total nymphal duration $(r=-0.402)$ was significantly negatively correlat-

Table 3. Morphometrics $(\mathrm{mm})$ of fourth instar nymphs of $A$. craccivora reared on different host plants.

\begin{tabular}{lcccccc}
\hline Host plants & $\begin{array}{c}\text { Body length } \\
\pm \text { S.D. }\end{array}$ & $\begin{array}{c}\text { Body width } \\
\pm \text { S.D. }\end{array}$ & $\begin{array}{c}\text { Antennal } \\
\text { length } \pm \text { S.D. }\end{array}$ & $\begin{array}{c}\text { Head capsule } \\
\text { width } \pm \text { S.D. }\end{array}$ & $\begin{array}{c}\text { Cornicle } \\
\text { length } \pm \text { S.D. }\end{array}$ & $\begin{array}{c}\text { Caudal } \\
\text { length } \pm \text { S.D. }\end{array}$ \\
\hline Cowpea & $1.56^{\mathrm{c}} \pm 0.01$ & $0.80^{\mathrm{c}} \pm 0.00$ & $0.81^{\mathrm{c}} \pm 0.03$ & $0.36^{\mathrm{b}} \pm 0.00$ & $0.20^{\mathrm{b}} \pm 0.02$ & $0.18^{\mathrm{b}} \pm 0.01$ \\
Groundnut & $1.25^{\mathrm{a}} \pm 0.03$ & $0.54^{\mathrm{a}} \pm 0.01$ & $0.54^{\mathrm{a}} \pm 0.01$ & $0.32^{\mathrm{a}} \pm 0.00$ & $0.10^{\mathrm{a}} \pm 0.01$ & $0.06^{\mathrm{a}} \pm 0.01$ \\
Greengram & $1.40^{\mathrm{b}} \pm 0.01$ & $0.72^{\mathrm{b}} \pm 0.01$ & $0.71^{\mathrm{b}} \pm 0.01$ & $0.32^{\mathrm{a}} \pm 0.01$ & $0.15^{\mathrm{ab}} \pm 0.00$ & $0.16^{\mathrm{b}} \pm 0.00$ \\
Blackgram & $1.32^{\mathrm{ab}} \pm 0.02$ & $0.55^{\mathrm{a}} \pm 0.01$ & $0.58^{\mathrm{a}} \pm 0.00$ & $0.33^{\mathrm{a}} \pm 0.00$ & $0.11^{\mathrm{a}} \pm 0.01$ & $0.07^{\mathrm{a}} \pm 0.01$ \\
\hline
\end{tabular}

Values followed by same letter are not significantly different at 0.05 level as per DMRT. 
Table 4. Morphometrics ( $\mathrm{mm}$ ) of sdults of $A$. craccivora reared on different host plants.

\begin{tabular}{lcccccc}
\hline Host plants & $\begin{array}{c}\text { Body length } \\
\pm \text { S.D. }\end{array}$ & $\begin{array}{c}\text { Body width } \\
\pm \text { S.D. }\end{array}$ & $\begin{array}{c}\text { Antennal } \\
\text { length } \pm \text { S.D. }\end{array}$ & $\begin{array}{c}\text { Head capsule } \\
\text { width } \pm \text { S.D. }\end{array}$ & $\begin{array}{c}\text { Cornicle } \\
\text { length } \pm \text { S.D. }\end{array}$ & $\begin{array}{c}\text { Caudal } \\
\text { length } \pm S . D .\end{array}$ \\
\hline Cowpea & $2.33^{\mathrm{b}} \pm 0.14$ & $1.18^{\mathrm{c}} \pm 0.02$ & $1.66^{\mathrm{b}} \pm 0.13$ & $0.44^{\mathrm{c}} \pm 0.02$ & $0.44^{\mathrm{b}} \pm 0.05$ & $0.31^{\mathrm{c}} \pm 0.02$ \\
Groundnut & $1.82^{\mathrm{a}} \pm 0.04$ & $0.93^{\mathrm{a}} \pm 0.04$ & $0.86^{\mathrm{a}} \pm 0.16$ & $0.32^{\mathrm{a}} \pm 0.00$ & $0.29^{\mathrm{a}} \pm 0.02$ & $0.16^{\mathrm{a}} \pm 0.01$ \\
Greengram & $1.96^{\mathrm{a}} \pm 0.15$ & $1.08^{\mathrm{b}} \pm 0.06$ & $1.50^{\mathrm{b}} \pm 0.08$ & $0.40^{\mathrm{b}} \pm 0.03$ & $0.37^{\mathrm{ab} \pm 0.02}$ & $0.22^{\mathrm{b}} \pm 0.01$ \\
Blackgram & $1.90^{\mathrm{a}} \pm 0.03$ & $0.95^{\mathrm{a}} \pm 0.07$ & $1.03^{\mathrm{a}} \pm 0.28$ & $0.37^{\mathrm{b}} \pm 0.01$ & $0.37^{\mathrm{ab}} \pm 0.02$ & $0.19^{\mathrm{ab}} \pm 0.05$ \\
\hline
\end{tabular}

Values followed by same letter are not significantly different at 0.05 level as per DMRT.

ed and adult longevity $(r=0.435)$ and fecundity $(r=0.443)$ positively correlated with protein content. Total nymphal duration $(\mathrm{r}=-0.399)$, adult longevity $(\mathrm{r}=-0.462)$, fecundity $(r=-0.479)$, total life cycle $(r=-0.522)$ were significantly negatively correlated and nymphal mortality $(\mathrm{r}$ $=0.408)$ significantly positively correlated with phenol content of the host plants. Adult longevity $(\mathrm{r}=0.755)$, fecundity $(r=0.737)$, total life span $(r=0.757)$ were significantly correlated and nymphal mortality $(\mathrm{r}=-0.705)$ negatively correlated (significance at 0.01 level) with the free amino acid contents of the host plants. Nymphal duration $(\mathrm{r}=-0.072)$, fecundity $(\mathrm{r}=-0.563)$, adult longevity $(\mathrm{r}=-0.555)$, total life span $(\mathrm{r}=-0.559)$ were significantly negatively correlated and percentage nymphal mortality $(\mathrm{r}$ $=0.589$ ) positively correlated with the reducing sugar content of the host plants (Table 6).

\section{Number of aphids consumed by $C$. sexmaculata}

During the entire larval period of the coccinellid, the highest number of aphids were consumed when the aphids were reared on groundnut (229.25 \pm 12.99 aphids) followed by greengram (214.25 \pm 46.77 aphids), blackgram (212.50 \pm 19.05 aphids) and cowpea (197.50 \pm 11.93 aphids) (not significantly different). The least number of aphids were consumed, when they were reared on cotton $(85.75 \pm 34.15$ aphids) followed by sunflower (109.25 \pm 10.71 aphids) (not significantly different) (Table 7).

The number of aphids consumed by adult male beetles was highest when they were provided with aphids reared on groundnut (588.5 \pm 27.57 aphids), which is statistically significantly different from that consumed when provided with aphids reared on the other host plants. The least numbers of aphids consumed by adult male beetles were recorded when they were provided with aphids reared on cotton $(425.00 \pm 17.89$ aphids) and sunflower $(469.11 \pm 28.46$ aphids) (not significantly different). The numbers of aphids consumed by adult male beetles when they were provided with aphids reared on greengram $(539.23 \pm 32.13$ aphids), cowpea (519.5 \pm 14.84 aphids) and blackgram (509.00 \pm 37.87 aphids) did not differ significantly and were intermediate between the number aphids reared on groundnut and cotton consumed (Table 7).

Adult female beetles consumed the highest numbers of aphids when they were provided with aphids reared on groundnut (903.00 \pm 39.59 aphids), which is statistically different from when they were provided with aphids reared on the other host plants. Adult female beetles consumed the lowest number of aphids when they were provided with aphids reared on cotton (528.00 \pm 12.72 aphids) followed by sunflower ( $547.00 \pm 9.89$ aphids) (not statistically different) (Table 7).

\section{DISCUSSION}

This study revealed that $A$. craccivora did significantly best when reared on cowpea (shortest developmental time and lowest nymphal mortality) followed by groundnut, greengram, blackgram, sunflower and cotton [highest nymphal mortality (Table 1)]. Based on the size (body length and width) of the different instars and adults this aphid did best when reared on cowpea and worst on groundnut. On cotton and sunflower, the nymphs did not survive to the adult stage (Table 1).

It is generally believed that aphids fed on poor quality host plants are smaller and lighter, take longer to develop and are more vulnerable to attack by natural enemies than those fed on high quality plants (Dhaliwal \& Dilwari, 1993). Partial plant resistance coupled with the action of predators is a more effective way of reducing the number of aphids infesting faba bean than either predator or plant resistance alone (Shannag \& Obeidat, 2008). In the present

Table 5. Biophysical and biochemical characteristics of the different host plants.

\begin{tabular}{|c|c|c|c|c|c|c|}
\hline \multirow{2}{*}{ Host plants } & \multirow{2}{*}{$\begin{array}{c}\text { Physical } \\
\text { characteristics } \\
\text { Trichome density / } \\
0.25 \mathrm{~cm}^{2} \text { leaf area }\end{array}$} & \multicolumn{5}{|c|}{ Biochemical characteristics } \\
\hline & & $\begin{array}{l}\text { Protein (mg/g wt. } \\
\text { of fresh leaf) }\end{array}$ & $\begin{array}{l}\text { TSS (mg/g wt. } \\
\text { of fresh leaf) }\end{array}$ & $\begin{array}{l}\text { Phenol (mg/g wt. } \\
\text { of fresh leaf) }\end{array}$ & $\begin{array}{l}\text { FAA (mg/g wt. } \\
\text { of fresh leaf) }\end{array}$ & $\begin{array}{c}\text { Reducing sugars } \\
\text { (mg/g wt. of fresh leaf) }\end{array}$ \\
\hline Cowpea & $0.00^{\mathrm{a} \pm} 0.00$ & $335.21^{d} \pm 29.58$ & $13.04^{c} \pm 1.34$ & $49.29^{a} \pm 17.04$ & $5.68^{d} \pm 2.26$ & $1.82^{a} \pm 0.38$ \\
\hline Groundnut & $17.3^{\mathrm{a} \pm} 8.40$ & $203.01^{b} \pm 38.32$ & $7.49^{a} \pm 2.06$ & $76.43^{a} \pm 29.22$ & $3.49^{c} \pm 0.82$ & $1.96^{\mathrm{a}} \pm 0.22$ \\
\hline Greengram & $78.8^{b} \pm 19.43$ & $220.65^{b c} \pm 10.55$ & $11.22^{\mathrm{bc}} \pm 0.82$ & $91.71^{a} \pm 20.28$ & $4.04^{\mathrm{cd}} \pm 1.06$ & $2.06^{a} \pm 0.08$ \\
\hline Blackgram & $86.7^{b} \pm 23.65$ & $275.01^{\mathrm{dc}} \pm 76.73$ & $10.06^{b} \pm 1.74$ & $97.15^{\mathrm{a}} \pm 50.58$ & $2.32^{b c} \pm 0.47$ & $2.21^{a b} \pm 0.09$ \\
\hline Sunflower & $152.1^{\mathrm{c}} \pm 42.89$ & $139.53^{\mathrm{a}} \pm 26.13$ & $16.14^{\mathrm{d}} \pm 1.76$ & $92.97^{\mathrm{a}} \pm 7.42$ & $0.40^{\mathrm{a}} \pm 0.41$ & $3.15^{\mathrm{c}} \pm 0.23$ \\
\hline Cotton & $265.9^{d} \pm 78.97$ & $306.06^{d} \pm 71.92$ & $5.53^{a} \pm 0.92$ & $260.46^{b} \pm 31.43$ & $1.24^{\mathrm{ab}} \pm 0.54$ & $2.58^{b} \pm 0.61$ \\
\hline
\end{tabular}

Values followed by same letter are not significantly different at 0.05 level as per DMRT; TSS - Total Soluble Sugars; FAA - Free Amino Acids. 
Table 6. Correlation (Pearson) ("r" values) between the different growth parameters of the aphids and different host plant characters (biophysical and biochemical).

\begin{tabular}{|c|c|c|c|c|c|c|}
\hline \multirow{2}{*}{$\begin{array}{l}\text { Growth } \\
\text { parameters }\end{array}$} & \multicolumn{6}{|c|}{ Host plant characters } \\
\hline & $\begin{array}{l}\text { Trichome density I } \\
0.25 \mathrm{~cm}^{2} \text { leaf area }\end{array}$ & $\begin{array}{l}\text { Protein (mg/g wt. } \\
\text { of fresh leaf) }\end{array}$ & $\begin{array}{l}\text { TSS (mg/g wt. } \\
\text { of fresh leaf) }\end{array}$ & $\begin{array}{l}\text { Phenol (mg/g wt. } \\
\text { of fresh leaf) }\end{array}$ & $\begin{array}{c}\text { FAA (mg/g wt. } \\
\text { of fresh leaf) }\end{array}$ & $\begin{array}{c}\text { Reducing sugars (mg/g } \\
\text { wt. of fresh leaf) }\end{array}$ \\
\hline Nymphal duration & -0.129 & $-0.402^{*}$ & 0.215 & $-0.399 *$ & 0.083 & -0.072 \\
\hline $\begin{array}{l}\text { Percentage } \\
\text { nymphal mortality }\end{array}$ & $0.682^{* *}$ & -0.279 & -0.069 & $0.408^{*}$ & $-0.705^{\star \star}$ & $0.589 * *$ \\
\hline Adult longevity & $-0.752^{\star *}$ & $0.435^{*}$ & 0.126 & $-0.462^{*}$ & $0.755^{\star *}$ & $-0.555^{\star *}$ \\
\hline Fecundity & $-0.799 * *$ & $0.443^{*}$ & 0.128 & $-0.479 *$ & $0.737^{* *}$ & $-0.563^{* *}$ \\
\hline Total life span & $-0.762^{\star \star}$ & 0.360 & 0.161 & $-0.522^{\star *}$ & $0.757^{* *}$ & $-0.559 * \star$ \\
\hline
\end{tabular}

* Correlation is significant at the 0.05 level (2-tailed). ${ }^{* *}$ Correlation is significant at the 0.01 level (2-tailed). TSS - Total Soluble Sugars; FAA - Free Amino Acids.

study, the poor quality of groundnut might account for the small size of the aphids reared on this plant and the high quality of cowpea for the large size of the aphids reared on this plant. The low nymphal mortality of aphids when reared on cowpea could be due to its high protein content, low density of trichomes and low phenol content (Table 5). The high phenol content and high trichome density of cotton and sunflower might account for the high aphid nymphal mortality recorded on these plants. This aphid failed to complete its development on these two plants (Table 1).

It is well documented that plant trichomes (glandular and non glandular) act as barriers (antixenosis resistance) to movement and reduce the survival of aphids (Farrar \& Kennedy, 1991; Simmons et al., 2003; van Emden, 2007). This is also the case for biochemical constituents such as plant secondary metabolites. A. gossypii has a shorter adult life and lower fecundity when reared on varieties of cotton with a high polyphenol gossypol content (Du et al., 2004). Wheat cultivars with a high Hydroxamic acid content are more resistant to attack by Sitobion avenae and its growth is negatively correlated with Hx levels (Fuentes-Contreras \& Niemeyer, 1998).

Because of the low nutritional quality of groundnut, aphids reared on this plant are small and both larvae and adults of $C$. sexmaculata need to consume more aphids when on groundnut (Table 7). In contrast, because of the high nutritional quality of cowpea, aphids reared on this plant are large (Table 3 and 4) and both the larvae and adults of $C$. sexmaculata need to consume fewer aphids when on cowpea (Table 7). Similar findings are reported by Barkhordar et al. (2013). They studied the effect of host plant resistance in the tri-trophic interaction between wheat genotypes, the aphid, Schizaphis graminum, and the coccinellid beetle, Coccinella septempunctata. They report that the low weight and small size of the aphids reared on resistant genotypes resulted in the ladybird eating more aphids per unit time on these plants. Messina \& Sorenson (2001), studying tri-tropic interactions involving larvae of the lacewing Chrysoperla plorabunda (Fitch) and aphids reared on resistant and susceptible wheat cultivars, found that lacewing larvae caused a greater reduction in density of Russian wheat aphid, Diuraphis noxia (Mordvilko) on a tolerant-resistant line (carrying the Dn4 gene) than on its near-isogenic susceptible parent. Similarly, Giles et al. (2002) report an increase in survival rate, decrease in developmental time and larger Coccinella septempunctata, when fed on the aphid Aphis pisum reared on Medicago sativa, than when fed aphids reared on Vicia faba, They report that the tritrophic interactions appear to be modulated by the response of $A$. pisum to the biochemical constituents in the host plants. The aphid, Myzus persicae fed on sweet pepper is a more suitable food for the lady beetle, Adalia bipunctata due its better nutritive value; whereas the same aphid fed on tabacco is less suitable because it is toxic (Jalali \& Michaud, 2012).

The study on the effect of the biophysical and biochemical constituents of the host plants (Table 5), revealed that both cotton and sunflower had significantly higher numbers of trichomes and higher quantities of phenols. Both trichomes and phenols had a significant negative effect on the aphid's biological characters and positive effect on aphid nymphal mortality (Table 6). It is concluded that the high quantity of phenols and high trichome density of cotton and sunflower resulted in the poor performance of the

Table 7. The number of aphids reared on the different host plants consumed by the larvae and adults of the coccinellid beetle (C. sexmaculata Fab.).

\begin{tabular}{lccccccc}
\hline Host plants & $\begin{array}{c}\text { First instar } \\
\text { larva } \pm \text { S.D. }\end{array}$ & $\begin{array}{c}\text { Second instar } \\
\text { larva } \pm \text { S.D. }\end{array}$ & $\begin{array}{c}\text { Third instar } \\
\text { larva } \pm \text { S.D. }\end{array}$ & $\begin{array}{c}\text { Fourth instar } \\
\text { larva } \pm \text { S.D. }\end{array}$ & $\begin{array}{c}\text { Total consumption } \\
\text { during entire larval } \\
\text { period } \pm \text { S.D. }\end{array}$ & $\begin{array}{c}\text { Adult male } \\
\text { consumption } \\
\pm \text { S.D. }\end{array}$ & $\begin{array}{c}\text { Adult female } \\
\text { consumption } \\
\pm \text { S.D. }\end{array}$ \\
\hline Cowpea & $11.00^{\mathrm{ab}} \pm 2.44$ & $11.25^{\mathrm{a}} \pm 1.25$ & $44.50^{\mathrm{ab}} \pm 5.19$ & $130.75^{\mathrm{b}} \pm 14.43$ & $197.50^{\mathrm{b}} \pm 11.93$ & $519.5^{\mathrm{b}} \pm 14.84$ & $680.00^{\mathrm{b}} \pm 29.69$ \\
Groundnut & $17.50^{\mathrm{a}} \pm 1.91$ & $22.25^{\mathrm{b}} \pm 5.56$ & $39.25^{\mathrm{ab}} \pm 6.70$ & $150.25^{\mathrm{b}} \pm 13.43$ & $229.25^{\mathrm{b}} \pm 12.99$ & $588.5^{\mathrm{c}} \pm 27.57$ & $903.00^{\mathrm{d}} \pm 39.59$ \\
Greengram & $13.75^{\mathrm{bc}} \pm 3.09$ & $15.25^{\mathrm{a}} \pm 4.34$ & $47.25^{\mathrm{b}} \pm 17.25$ & $135.00^{\mathrm{b}} \pm 36.36$ & $214.25^{\mathrm{b}} \pm 46.77$ & $539.23^{\mathrm{b}} \pm 32.13$ & $757.66^{\mathrm{c}} \pm 25.02$ \\
Blackgram & $12.50^{\mathrm{ab}} \pm 5.06$ & $16.00^{\mathrm{a}} \pm 3.16$ & $48.75^{\mathrm{b}} \pm 1.70$ & $137.75^{\mathrm{b}} \pm 14.24$ & $212.50^{\mathrm{b}} \pm 19.05$ & $509.00^{\mathrm{b}} \pm 37.87$ & $797.33^{\mathrm{c}} \pm 20.40$ \\
Sunflower & $9.75^{\mathrm{ab}} \pm 2.21$ & $11.00^{\mathrm{a}} \pm 2.82$ & $35.25^{\mathrm{ab}} \pm 1.70$ & $53.25^{\mathrm{a}} \pm 13.96$ & $109.25^{\mathrm{a}} \pm 10.71$ & $469.11^{\mathrm{a}} \pm 28.46$ & $547.00^{\mathrm{a}} \pm 9.89$ \\
Cotton & $8.50^{\mathrm{a}} \pm 2.88$ & $10.75^{\mathrm{a}} \pm 2.62$ & $31.25^{\mathrm{a}} \pm 7.93$ & $35.25^{\mathrm{a}} \pm 24.38$ & $85.75^{\mathrm{a}} \pm 34.15$ & $425.00^{\mathrm{a}} \pm 17.89$ & $528.00^{\mathrm{a}} \pm 12.72$ \\
\hline
\end{tabular}

Values followed by same letter are not significantly different at $0.05 \%$ as per DMRT. 
aphids reared on these plants (Table 1 and 2). Consequently, when both larvae and adults of $C$. sexmaculata were provided with aphids reared on cotton and sunflower they consumed far fewer of these aphids than of those reared on the other host plants. The biochemical constituents (phenols) in cotton and sunflower that resulted in the high aphid nymphal mortality on these plants (Table 1), might also have affected the feeding behaviour of the coccinellid (third trophic level) (Table 7).

Several workers have hypothesised that the harmfulness of certain aphid prey for their aphidophagous predators results from the presence of toxic plant biochemical constituents (Malcom, 1990; Hodek \& Honek, 1996; Francis et al., 2000). The present results provide an insight into the negative effect host plants (based on their secondary metabolites) can have on the third trophic level. However, contrary to the present findings, Du et al. (2004) report that high levels of gossypol in cotton had an antibiotic effect on Aphis gossypii but a positive effect on the growth and development of Propylea japonica in the third trophic level. The toxic aphid Aphis sambuci is consumed by larvae and adults of Coccinella septempunctata at twice the rate as that of two essential species of prey Acyrthosiphum pisum and Aphis philadelphi (Nedved \& Salvucci, 2008). The result may be due to the fact that the period the prey were exposed to the predator was only four hours and the predators were starved prior to the onset of the experiment. It is believed that starved predators generally do not distinguish between toxic and non toxic prey. However in the present study the predators were allowed to feed on insect prey (reared on different host plants) throughout their larval and adult development and hence the differences are apparent.

It can be argued that plant secondary metabolites have a negative effect on herbivores in reducing their fitness and making them more vulnerable to both natural enemies and abiotic conditions. However, this is not always the case as when the host plant is favourable for the herbivore it is also likely to be favourable prey for its natural enemies as seen in the case of groundnut in this study. However, if the secondary metabolites are toxic, as in the case of cotton and sunflower in this study, the negative effect on the herbivore may also have a negative effect on its natural enemies.

\section{CONCLUSIONS}

It is concluded that it is necessary to carry out detailed and comprehensive trophic level studies before advocating the use of partial plant resistance (based solely on secondary metabolites) in insect pest management, as the secondary metabolites present in host plants could affect the efficacy of the predators in the third trophic level (van Emden, 1995).

\section{REFERENCES}

Barkhordar B., Khalghani J., Jouzani G.S., Ganbalani G.N., Shojail M., Boustani M.T., Karimi E., Soheiliv S. \& Hosseini B. 2013: Impact of host plant resistance on the tritrophic interactions between wheat genotypes, Schizaphis graminum (Homoptera: Aphididae) and Coccinella septempunctata (Coleo- ptera: Coccinellidae) using molecular methods. - Environ. Entomol. 42: 1118-1122.

CAB International 2016: Datasheet - Aphis craccivora. URL: http://www.cabi.org/isc/datasheet/6192.

Dhaliwal G.S. \& Dilwari V.K. 1993: Advances in Host Plant Resistance to Insects. Kalyani, New Delhi, pp. 178-179.

Down R.E., Ford L., Woddhouse S.D., Davison G.M., Majerus M.E., Gatehouse J.A. \& Gatehouse A.M. 2003: Tritrophic interactions between transgenic potato expressing snowdrop lectin (GNA), on an aphid pest (peach-potato aphid; Myzus persicae (Sulz.) and a beneficial predator (2-spoted ladybird; Adalia bipunctata L.). - Transgenic Res. 12: 229-241.

Du Li., Ge F., Zhu S. \& Parajulee M.N. 2004: Effect of cotton cultivar on development and reproduction of Aphis gossypii (Homoptera: Aphididae) and its predator Propylaea japonica (Coleoptera: Coccinellidae). — J. Econ. Entomol. 97: 12781283.

Durcher J.D., Estes P.M. \& Dutcher M.J. 1999: Interactions in entomology: aphids, aphidophaga and ants in pecan orchards. - J. Entomol. Sci. 34: 40-56.

VAN EMDEN H.F. 1995: Host plant-Aphidophaga interactions. Agric. Ecosyst. Environ. 52: 3-11.

VAN EMDEN H.F. 2007: Host-plant resistance. In van Emden H.F. \& Harrington R. (eds): Aphids as Crop Pests. CABI, Wallingford, pp. 447-468.

FARRAR R.R. \& KENNEDY G.G. 1991: Insect and mite resistance in tomato. In Kalloo G. (ed.): Genetic Improvement of Tomato. Monographs on Theoretical and Applied Genetics, 14. Springer, Berlin, pp. 121-142.

Francis F., Haubruge E. \& Gaspar C. 2000: Influence of host plant on specialist/generalist aphids on the development of Adalia bipunctata (Coleoptera: Coccinellidae). — Eur. J. Entomol. 97: 481-485.

Fuentes-Contreras J.E. \& Niemeyer H.M. 1998: DiMBOA glucoside, a wheat chemical defense, affects host acceptance and suitability of Sitobion avenae to the cereal aphid parasitoid Aphidius rhopalosiphi. - J. Chem. Ecol. 24: 371-381.

Giles K.L., Berberet R.C., Zarrabi A.A. \& Dillwith J.W. 2002: Influence of alfalfa cultivar on suitability of Acyrthosiphon kondoi (Homoptera: Aphididae) for survival and development of Hippodamia convergens and Coccinella septempunctata (Coleoptera: Coccinellidae). - J. Econ. Entomol. 95: 552-557.

Hedge J.F. \& Hofreiter B.T. 1962: Methods of estimating starch and carbohydrates. In Whistler R.L. \& Miller J.N.B. (eds): Carbohydrate Chemistry 17. Academic Press, New York, pp. 163-201.

Hodek I. \& Honek A. 1996: Ecology of Coccinellidae. Kluwer, Dordrecht, $464 \mathrm{pp}$.

JALALI M.A. \& Michaud J.P. 2012: Aphid-plant interactions affect the suitability of Myzus spp. as prey for the two spot ladybird, Adalia bipunctata. - Eur. J. Entomol. 109: 345-352.

KenNedy G.G. 2003: Tomato, pests, parasitoids and predators: Tritrophic interactions involving the genus Lycopersicon. Annu. Rev. Entomol. 48: 51-72.

Lowry O.H., Rosebrough N.J., FarR A.L. \& Ramdall R.J. 1951: Protein measurement with the folin phenol reagent. - J. Biol. Chem. 193: 265-275.

MaLcom S.B. 1990: Chemical defence in chewing and sucking insect herbivores: plant-derived cardenolides in the monarch butterfly and oleander aphid. - Chemoecology 1: 12-21.

Malick C.P. \& Singh M.B. 1980: Plant Enzymology and HistoEnzymology. Kalyani, New Delhi, 281 pp.

Messina F.J. \& SoREnson S.M. 2001: Effectiveness of lacewing larvae in reducing Russian wheat aphid populations on susceptible and resistant wheat. - Biol. Contr. 21: 19-26. 
Moore S. \& STEIN W.H. 1948: Analysis of amino acids. In Colowick S.P \& Kalpan N.D (eds): Methods in Enzymology. Academic Press, New York, pp. 468-471.

Nedved O. \& Salvucci S. 2008: Ladybird Coccinella septempunctata (Coleoptera: Coccinellidae) prefers toxic prey in laboratory choice experiment. — Eur. J. Entomol. 105: 431-436.

ODE P.J. 2006: Plant chemistry and natural enemy fitness: effects on herbivore and natural enemy interactions. - Annu. Rev. Entomol. 51: 163-185.

Price P.W., Bouton C.E., Gross P., McPheron B.A., Thompson J.N. \& WeIs A.E. 1980: Interaction between three trophic levels: influence of plants on interactions between insect herbivores and natural enemies. - Annu. Rev. Ecol. Syst. 11: 41-65.

Rahman M.H., Sardar M.A., Miah M.R.U. \& Kamal N.Q. 1993 Consumption rate of Aphis medicaginis by the grubs of Menochilus sexmaculatus Fab. - Bangl. J. Zool. 21: 185-187.

Shannag H.K. \& Obeidat W.M. 2008: Interaction between plant resistance and predation of Aphis fabae (Homoptera: Aphididae) by Coccinella septempunctata (Coleoptera: Coccinellidae). - Ann. Appl. Biol. 152: 331-337.
Simmons A.T., Gurr G.M., McGrath D., Nicol H.I. \& Martin P.M. 2003: Trichomes of Lycopersicon spp. and their effect on Myzus persicae. - Aust. J. Entomol. 42: 373-378.

Solangi B.K., Hullio M.H. \& Baloch N. 2007: Biological parameters and prey consumption by zigzag beetle Menochilus sexmaculatus Fab. against Rhopalosiphum maidis Fitch, Aphis gossypii Glov. and Therioaphis trifolii Monell. - Sarhad J. Agric. 23: 1097-1110.

Somogyi M. 1952: Notes on sugar determination. - J. Biol. Chem. 195: 19-24.

SPSS Inc. 2004: SPSS 13.0 for Windows. URL: www.spss.com. Zhao J., Li S., Gao X.W., Zhang F. \& Wang S. 2015: Comparison of life tables of Cheilomenes sexmaculata (Coleoptera: Coccinellidae) under laboratory and greenhouse conditions. $-J$. Econ. Entomol. 108: 1700-1707.

Received August 26, 2016; revised and accepted October 27, 2016 Published online November 28, 2016 